REPORTS OF MORPHOLOGY
$\begin{gathered}\text { Official Journal of the Scientific Society of Anatomists, } \\ \text { Histologists, Embryologists and Topographic Anatomists } \\ \text { of Ukraine } \\ \text { journal homepage: https://morphology-journal.com }\end{gathered}$

\title{
Normal values of coronary arteries branching height in women
}

\section{Pidvalna U.Ye. ${ }^{1}$, Beshley D.M. ${ }^{1,2,3}$, Mirchuk M.Z. ${ }^{1,3}$, Mateshuk-Vatseba L.R. ${ }^{1}$}

${ }^{1}$ Danylo Halytsky National Medical University of Lviv, Lviv, Ukraine

${ }^{2}$ Lviv Regional Clinical Hospital, Lviv, Ukraine

3Ukrainian-Polish Heart Center "Lviv", Lviv, Ukraine

\section{ARTICLE INFO}

Received: 31 August 2021

Accepted: 1 October 2021

UDC: $611.132 .2-055.2-071.3$

\section{CORRESPONDING AUTHOR \\ e-mail: uljaska.p@gmail.com Pidvalna U.Ye.}

\section{CONFLICT OF INTEREST}

The authors have no conflicts of interest to declare.

\section{FUNDING}

The work was financially supported by the Danylo Halytsky National Medical University of Lviv, Ministry of Health of Ukraine (№ state registration: 0120U002129).
Morphometric analysis of the structures of the aortic bulb and coronary arteries is necessary for the planning of cardiac surgery and endovascular interventions. The aim of the study was to determine the height of the coronary arteries branching in healthy women of Lviv city and Lviv region and to determine the relationship between the height of the location of the orifice of the coronary artery with anthropometric indicators. Fifteen computed tomography images with contrast of female thorax without heart and ascending aortic lesions (normal) were selected for the study. The height of the upper and lower edges of the coronary arteries was measured; height of Valsalva sinuses. The comparison of the mean values was performed according to the Student's $t$-test. The correlation between the observed variables (age, height, body weight, body mass index, body surface area, height of the sinuses of Valsalva) was calculated using the Pearson linear correlation method ( $r$ ). According to the study, the population group consisted of persons of the second period of adulthood (46.67\%) and the elderly (53.33\%). According to the body mass index, $80 \%$ were overweight or obese I-Il degree. The mean height of the coronary artery orifice in women without structural changes of the heart and ascending aorta was: $11.19 \pm 1.96 \mathrm{~mm}$ for the left and $11.68 \pm 1.80 \mathrm{~mm}$ for the right. The height of the orifice of the right and left coronary arteries were almost the same, without statistical significance $(p=0.26)$. Analysis of the correlation between the values of the height of the orifice of the coronary artery did not show a probable dependence on height, weight, age, body mass index and body surface area. There is a direct relationship between the parameters of the height of the lower edge of the right coronary artery and the height of the upper edge of the right coronary artery $(r=+0.75, p=0.001)$ and between the value of the lower edge of the left coronary artery and the upper edge of the left coronary artery $(r=+0.63, p=0.01)$. Thus, the analysis of the correlation between the values of the height of the orifice of the coronary artery in women in norm and anthropometric indicators did not show a significant relationship. There was no statistical significance between the indicators of the height of the orifice of the right and left coronary arteries in women.

Keywords: orifice of the coronary artery, anatomy, computed tomography, aorta, measurements.

\section{Introduction}

The risk of cardiovascular disease is associated with anthropometric and sex indicators [10, 14]. Short stature is considered a factor in the development of coronary heart disease [8], which is closely associated with the risk of sudden coronary death [6]. Coronary arteries are a target for coronary heart disease. The right and left coronary arteries depart from the corresponding sinuses of Valsalva, which are part of the aortic bulb. Adequate assessment of aortic bulb anatomy is important in preoperative planning of cardiac surgery and endovascular interventions. The development of the latter, in particular transcatheter aortic valve implantation (TAVI), requires morphometric analysis of the structures of the aortic bulb and the orifice of the coronary artery [1].

Data on the height of coronary arteries in populations are quite variable $[7,9,13]$, which emphasizes the difficulty of unifying the range of aortic sizes in the norm [4]. Analysis of morphometric parameters of orifice of the coronary artery among the population of Ukraine in the professional scientific literature is not covered.

The aim of the study was to determine the height of the coronary arteries branching in healthy women of Lviv city 
and Lviv region and to determine the relationship between the height of the location of the orifice of the coronary artery with anthropometric indicators.

\section{Materials and methods}

The materials of the study are represented by computed tomography (CT) images with contrast of the thoracic organs of women without damage to the heart and ascending aorta (norm). Patients of the Lviv Regional Clinical Hospital (Lviv, Ukraine) were involved in the study. CT scans were performed at the Ukrainian-Polish Heart Center "Lviv" (Lviv, Ukraine). The studies were performed on a 64-slice multidetector computed tomograph LightSpeed VCT XT, GE (General Electric, USA). The survey was conducted in 3 stages: planning topograms, phase without contrast (native) and phase with contrast. Scanning type - helical. Introduction of contrast Ultravist 470 (Bayer Healthcare, Germany) at a rate of $4 \mathrm{ml} / \mathrm{s}$, followed by the introduction of sodium chloride solution (Arterium, Ukraine). Contrast volume was calculated for each patient individually, $\mathrm{kVp}$ and $\mathrm{mAs} /$ rotation were adjusted automatically depending on the patient's parameters. The survey protocol was performed according to the manufacturer's standards. CT analysis of angiography was performed at an appropriate station with licensed software (General Electric, USA) by two independent physicians.

Criteria for inclusion: CT of the chest with contrast; female patients; persons of the second period of mature age and old age; no complaints from the cardiovascular system; no history of cardiac surgery and endovascular interventions.

Exclusion criteria: patients with congenital malformations or abnormalities of the heart, coronary arteries and ascending aorta; inadequate visualization of the studied structures, incomplete clinical data.

The research was conducted in accordance with the Declaration of Helsinki and the approval of the Bioethics Committee of LNMU named after D. Halytsky, №5 dated July 22, 2020, with the informed consent of patients signed.

Of the 173 images analyzed, the study included data from 15 CT scans of the chest. The study used the following indicators: age, height, body weight, body mass index (BMI), body surface area. Body surface area was calculated by the formula of R. D. Mosteller [11]. All persons involved in the study were further divided into 2 groups depending on height: group 1 - females less than 1.6 meters tall $(n=6)$, group 2 - with a height of more than 1.61 $m(n=9)$. The average age of the surveyed persons was $57.37 \pm 14.33$ years, including persons of the second period of mature age (age limits $36-55$ years) and the elderly (elderly) age (age limits 56-74 years).

Image analysis was performed in horizontal (axial), sagittal and frontal (coronal) planes and 3D reconstruction. The height of the location of the upper and lower edges of both coronary arteries was measured; the height of the right, left and posterior sinuses of Valsalva. Measurements of the height of the left coronary artery were measured in the oblique frontal reformation, the right coronary artery - in the oblique sagittal reformation. The height of the lower edge of the coronary artery was measured as the distance from the ring of the aortic valve to the lower edge of the coronary artery. Height of the location of the upper edge of the coronary artery - the distance from the ring of the aortic valve to the upper edge of the coronary artery. The height of the sinuses of Valsalva is the distance from the ring of the aortic valve to the sinustubular junction. All measurements were made according to the step-by-step instructions in the appropriate planes and are given in millimeters [3].

Statistical analysis was performed using $R$ version 4.0.5 software ( $R$ Core Team, 2021) based on the Windows XP operating system using a personal computer [16]. The Shapiro-Francia test was used for correct distribution. The comparison of the mean values was performed according to the Student's t-test. The correlation between the observed variables was calculated using the Pearson linear correlation method ( $r$ ). Values are presented as arithmetic mean \pm standard deviation $(\mathrm{M} \pm \mathrm{SD})$ and in absolute numbers. The level of reliability $\mathrm{p}<0.05$ was considered reliable.

\section{Results}

According to clinical characteristics, the age of the persons was $57.37 \pm 14.33$ years, height $1.640 \pm 0.030 \mathrm{~m}$, body weight $77.40 \pm 14.47 \mathrm{~kg}$ and BMI $29.78 \pm 6.18 \mathrm{~kg} / \mathrm{m}^{2}$. According to age periodization: 7 persons of the second period of mature age $(46.67 \%)$ and 8 persons of elderly (elderly) age (53.33\%). According to the BMI classification:

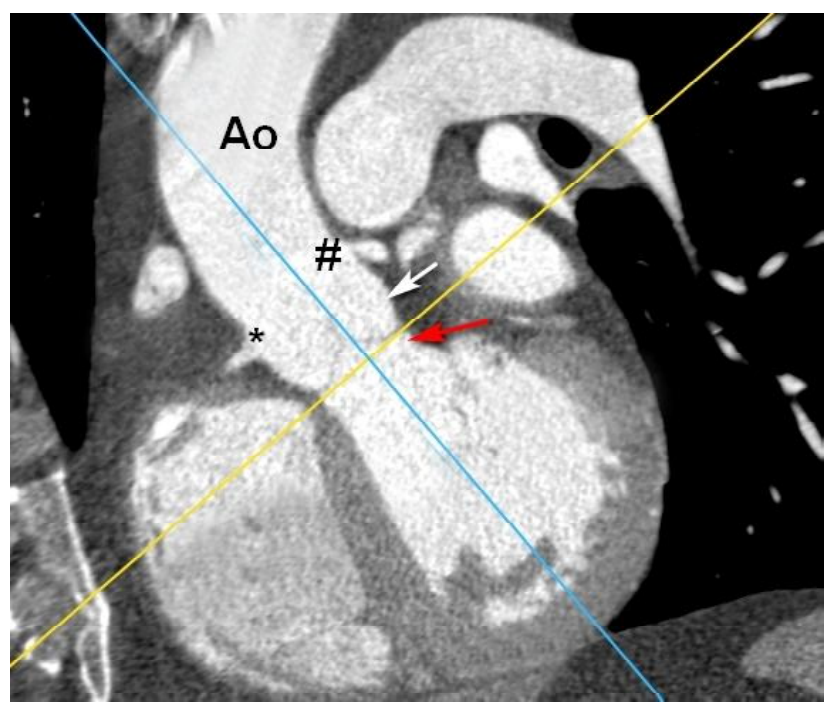

Fig. 1. Contrast-enhanced computed tomography of the chest. CT image visualizes the ascending aorta (Ao), aortic valve (red arrow), sinuses of Valsalva (white arrow), right coronary artery orifice $\left({ }^{*}\right)$, left coronary artery $(\#)$. 


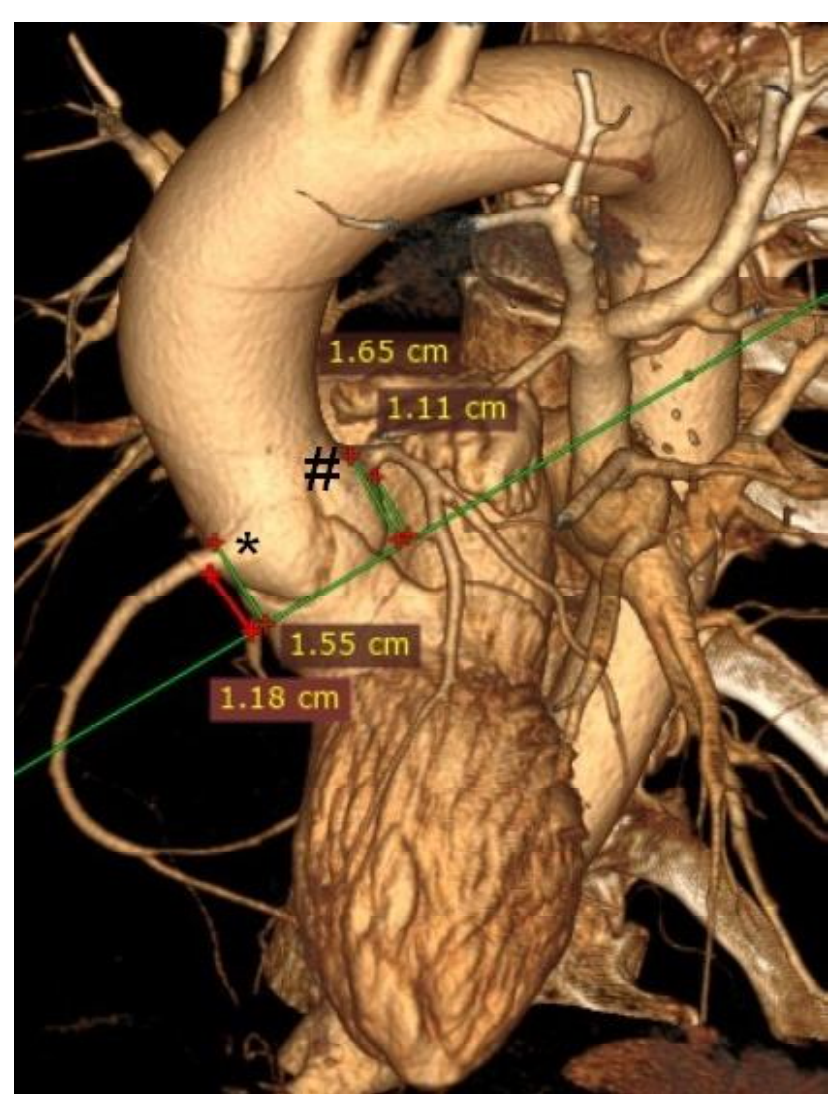

Fig. 2. Contrast-enhanced computed tomography of the chest. 3D-reconstruction visualizes the measurement of the height of the divergence of the right $\left(^{*}\right)$ and left (\#) coronary arteries.

3 people with normal weight $(20 \%), 6$ people with overweight (40\%), 4 people with grade I obesity $(26.67 \%)$ and 2 people with grade II obesity (13.33\%).

In women without structural changes in the heart and ascending aorta, the mean height of the left coronary artery was $11.19 \pm 1.96 \mathrm{~mm}$. The measured distance from the aortic valve ring to the lower and upper edge of the right coronary artery (Fig. 1,2) and to the lower and upper edge of the left coronary artery (Fig. 2, 3) differed between the studied groups: in the first group this figure was $10.57 \pm 2.03 \mathrm{~mm}$, in the second group $11.80 \pm 1.88 \mathrm{~mm}, \mathrm{p}=0.25$ (Table 1).

The mean height of the right coronary artery orifice in women was $11.68 \pm 1.80 \mathrm{~mm}$. According to the distribution by groups was $11.43 \pm 1.62 \mathrm{~mm}$ in the first group and $11.97 \pm 2.03 \mathrm{~mm}$ in the second, $p=0.57$. The height of the orifice of the right and left coronary arteries (Fig. 4) were almost the same, without statistical significance $(p=0.26)$.

The analysis of the correlation between the values of the height of the orifice of the coronary artery and anthropometric indicators did not show a significant dependence on height, which is actually explained by the above data of the highest values of the height of the orifice of the coronary artery in women of the second group. Data on the correlation between the height of the orifice of the coronary artery and height, weight, body mass index, body surface area and height of the sinuses of Valsalva are presented in Table 2.

It is logical to establish a direct relationship between the parameters of the height of the lower edge of the right coronary artery and the height of the upper edge of the right coronary artery $(r=+0.75, p=0.001)$ and between the value

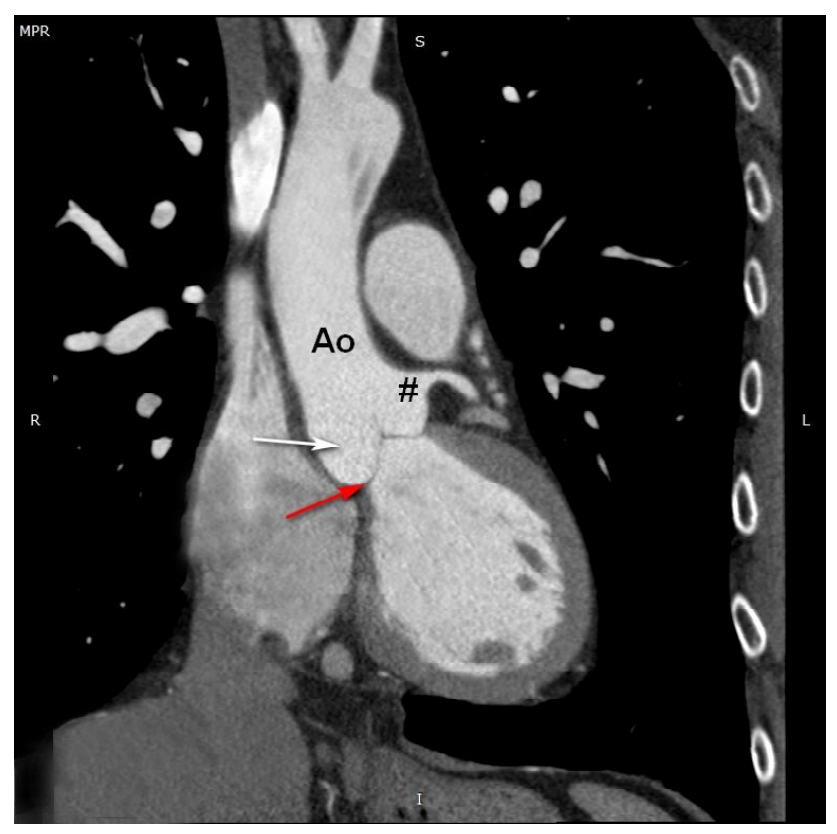

Fig. 3. Contrast-enhanced computed tomography of the chest. CT image visualizes the ascending aorta (Ao), aortic valve (red arrow), sinuses of Valsalva (white arrow), left coronary artery orifice (\#).

Table 1. Indicators of the height of the orifice of the coronary artery in women without structural damage to the heart and ascending aorta.

\begin{tabular}{|l|c|c|c|c|c|c|}
\hline \multirow{2}{*}{$\begin{array}{c}\text { Parameters } \\
(\mathrm{mm})\end{array}$} & Total & $\mathrm{n}=15$ & Group 1 & $\mathrm{n}=6$ & Group 2 & $\mathrm{n}=9$ \\
\cline { 2 - 7 } & $\mathrm{M} \pm \mathrm{SD}$ & $\mathrm{Me}[\mathrm{Q} 1 ; \mathrm{Q} 3]$ & $\mathrm{M} \pm \mathrm{SD}$ & $\mathrm{Me}[\mathrm{Q} 1 ; \mathrm{Q} 3]$ & $\mathrm{M} \pm \mathrm{SD}$ & $\mathrm{Me}[\mathrm{Q} 1 ; \mathrm{Q} 3]$ \\
\hline LCAI & $11.19 \pm 1.96$ & $10.8[9.9 ; 12.3]$ & $10.57 \pm 2.03$ & $10.3[9.0 ; 12.3]$ & $11.80 \pm 1.88$ & $10,9[10.4 ; 12.2]$ \\
\hline LCAu & $14.77 \pm 2.50$ & $14.9[13.5 ; 16.4]$ & $13.45 \pm 3.02$ & $13.5[12.0 ; 15.8]$ & $15.73 \pm 1.89$ & $15,2[14.7 ; 17.2]$ \\
\hline $\mathrm{RCAl}$ & $11.68 \pm 1.80$ & $11.3[10.4 ; 12.8]$ & $11.43 \pm 1.62$ & $11.3[10.1 ; 12.4]$ & $11.97 \pm 2.03$ & $12,4[10.4 ; 13.2]$ \\
\hline RCAu & $14.83 \pm 1.50$ & $14.8[13.9 ; 15.6]$ & $14.45 \pm 1.30$ & $14.7[13.3 ; 15.6]$ & $15.21 \pm 1.65$ & $15[14.5 ; 15.6]$ \\
\hline
\end{tabular}

Notes: LCAI - the height of the lower edge of the orifice of the left coronary artery; LCAu - the height of the upper edge of the orifice of the left coronary artery; RCAl - the height of the lower edge of the orifice of the right coronary artery; RCAu - the height of the upper edge of the orifice of the right coronary artery. 


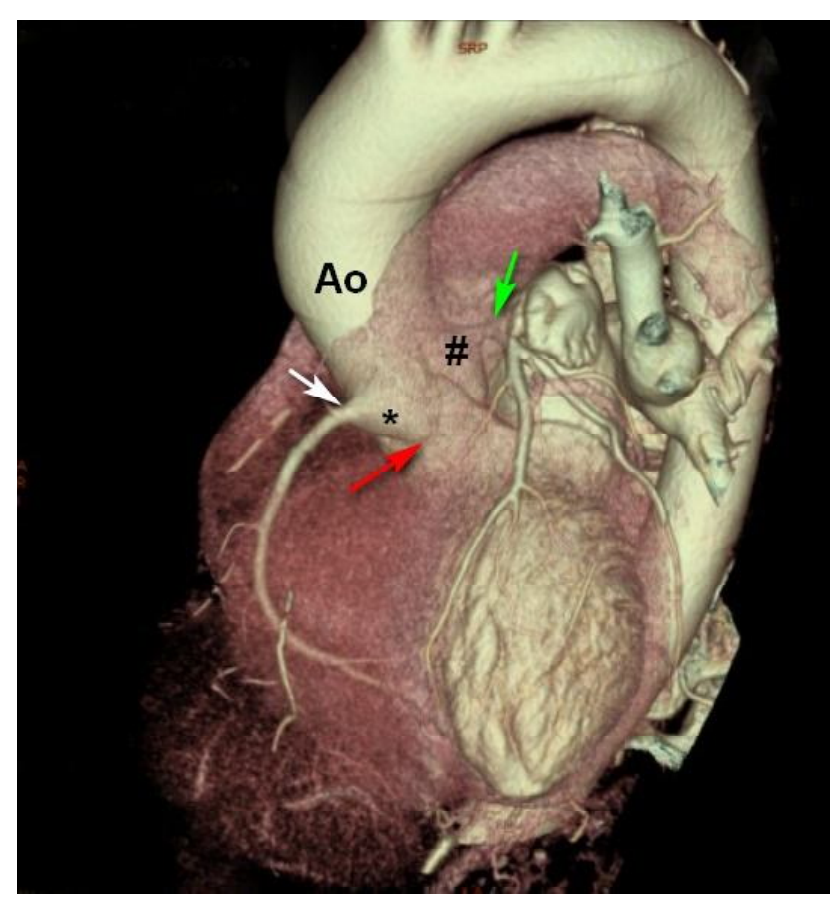

Fig. 4. Contrast-enhanced computed tomography of the chest. The 3D reconstruction visualizes the right sinuses of Valsalva $\left({ }^{*}\right)$, the left sinuses of Valsalva (\#), the aortic valve (red arrow), the right coronary artery (white arrow) and the left coronary artery (green arrow).

Table 2. Data on the correlation $(r)$ between the indicators of the height of the location of the orifice of the coronary artery and other studied indicators in women without structural damage to the heart and ascending aorta (norm).

\begin{tabular}{|l|c|c|c|c|}
\hline \multirow{2}{*}{\multicolumn{1}{|c|}{ Indicators }} & \multicolumn{2}{|c|}{$\begin{array}{c}\text { Height of discharge } \\
\text { of the left coronary } \\
\text { artery }\end{array}$} & \multicolumn{2}{c|}{$\begin{array}{c}\text { Height of discharge } \\
\text { of the right coronary } \\
\text { artery }\end{array}$} \\
\cline { 2 - 5 } & $\mathrm{r}$ & $\mathrm{p}$ & $\mathrm{r}$ & $\mathrm{p}$ \\
\hline Age & -0.04 & 0.89 & 0.44 & 0.09 \\
\hline Height & 0.03 & 0.90 & 0.17 & 0.54 \\
\hline Weight & 0.26 & 0.32 & 0.05 & 0.85 \\
\hline Body mass index & 0.25 & 0.35 & 0.00 & 1.00 \\
\hline Body surface area & 0.25 & 0.36 & 0.08 & 0.78 \\
\hline $\begin{array}{l}\text { Height of the right sinuses } \\
\text { of Valsalva }\end{array}$ & 0.07 & 0.80 & 0.30 & 0.25 \\
\hline $\begin{array}{l}\text { Height of the left sinuses } \\
\text { of Valsalva }\end{array}$ & 0.48 & 0.06 & 0.45 & 0.08 \\
\hline $\begin{array}{l}\text { Height of the posterior } \\
\text { sinuses of Valsalva }\end{array}$ & 0.10 & 0.72 & 0.43 & 0.10 \\
\hline $\begin{array}{l}\text { The height of the upper } \\
\text { edge of the orifice of the } \\
\text { right coronary artery }\end{array}$ & 0.54 & 0.03 & 0.75 & 0.001 \\
\hline $\begin{array}{l}\text { The height of the upper } \\
\text { edge of the orifice of the } \\
\text { left coronary artery }\end{array}$ & 0.63 & 0.01 & 0.44 & 0.09 \\
\hline
\end{tabular}

of the lower edge of the left coronary artery and an indicator of the height of the upper edge of the left coronary artery $(r=+0.63, p=0.01)$.

\section{Discussion}

The height of the orifice of the coronary artery discharge is an important parameter when planning cardiac surgery in pathology of the aortic valve and ascending aorta [2]. The high location of the right coronary artery at the appropriate height of the right sinuses of Valsalva is a frequent site of air embolism in cardiac surgery. Modern technique of transcatheter aortic valve implantation (TAVI) in the preoperative protocol requires measuring the height of the right and left coronary arteries [3, 6]. Underestimation of height can cause obstruction of the coronary artery [5].

The study measured the discharge of coronary arteries in women of Lviv city and Lviv region in the norm, aged over 18 years using computed tomography with contrast. It is valuable to analyze these data in the norm, which is not easy to carry out, given several points. First, contrast-enhanced computed tomography is performed according to clear indications under the direction of a physician. Second, creatinine and urea levels should be constant before the test. As a result, out of the large number of women surveyed (173 surveys), the images of 15 people corresponded to the norm. The study group consisted of persons of the second period of adulthood (ages 36-55 years) and the elderly (elderly) (ages 56-74). According to the body mass index, only $20 \%$ of people corresponded to the level of normal weight. $80 \%$ (12 people) were overweight or obese I-II degree.

According to the results of the study, in women there was no statistically significant relationship between the values of the height of the orifice of the coronary artery and indicators of age, height, weight, body mass index and body surface area. These data are consistent with the results published by Stolzmann [15], according to which age and BMI do not affect the height orifice of the coronary artery in women $(p>0.05)$. According to a retrospective analysis conducted in Italy, biometric parameters are low correlated with the size of the aorta [4]. Instead, H. Wang and co-authors (2021) report that age affects the size of the aorta. It is important to note that in women, in contrast to men, age does not correlate with the height of the discharge orifice of the coronary artery [17].

Data on the relationship between the height of the right and left coronary arteries differ significantly. In a study conducted by Swiss radiologists and cardiac surgeons, a statistically significant difference $(p<0.001)$ between the orifice height of the right and left coronary arteries was confirmed in the general population [15]. In contrast, data from the African continent indicate a slightly higher location of the eye of the left coronary artery than the right [12]. According to the results of our study, in females the height of the orifice of the right and left coronary arteries were almost the same, without statistical significance $(p=0.26)$.

Measuring the distance from the aortic valve ring to the lower edge of the coronary artery, we found that in women without structural changes in the heart and ascending aorta, the average height of the left coronary artery orifice is 
$11.19 \pm 1.96 \mathrm{~mm}$, the average height of the right coronary arteries orifice $-11.68 \pm 1.80 \mathrm{~mm}$. Drawing a parallel with previously published studies, we found that the distances are very variable $[7,9,12,15,17]$. The reasons for this are: geographical, racial, demographic and sex differences; use of various diagnostic methods for assessment (CT angiography, coronary angiography, esophageal $\mathrm{ECHO}$, autopsy); difference in measurement technique. It would be rational to compare the data obtained by us with other regions of Ukraine. Unfortunately, the analysis of the professional literature showed that such studies have not been conducted.

The obtained results create prospects for the implementation of morphometric data in clinical practice. Globally, the study will complement world data, taking into account the peculiarities of anthropometric data of females

\section{References}

[1] Astudillo, P., Mortier, P., Bosmans, J., De Backer, O., de Jaegere, P., lannaccone, F., \& Dambre, J. (2020). Automatic Detection of the Aortic Annular Plane and Coronary Ostia from Multidetector Computed Tomography. Journal of Interventional Cardiology, 2020. doi: $10.1155 / 2020 / 9843275$

[2] Bahlmann, E., Nienaber, C. A., Cramariuc, D., Gohlke-Baerwolf, C., Ray, S., Devereux, R. B., \& Gerdts, E. (2011). Aortic root geometry in aortic stenosis patients (a SEAS substudy). European Journal of Echocardiography, 12(8), 585-590. doi: 10.1093/ejechocard/jer037

[3] Blanke, P., Weir-McCall, J. R., Achenbach, S., Delgado, V., Hausleiter, J., Jilaihawi, H., \& Leipsic, J. A. (2019). Computed tomography imaging in the context of transcatheter aortic valve implantation (TAVI) / transcatheter aortic valve replacement (TAVR): An expert consensus document of the Society of Cardiovascular Computed Tomography. Journal of Cardiovascular Computed Tomography, 13(1), 1-20. doi: 10.1016/j.jcct.2018.11.008

[4] Forte, E., Punzo, B., Salvatore, M., Maffei, E., Nistri, S., Cavaliere, C., \& Cademartiri, F. (2020). Low correlation between biometric parameters, cardiovascular risk factors and aortic dimensions by computed tomography coronary angiography. Medicine, 99(35). doi: 10.1097/MD.0000000000021891

[5] Heitkemper, M., Sivakumar, S., Hatoum, H., Dollery, J., Lilly, S. M., \& Dasi, L. P. (2020). Simple 2-dimensional anatomic model to predict the risk of coronary obstruction during transcatheter aortic valve replacement. The Journal of Thoracic and Cardiovascular Surgery, S0022-5223, 30435-30439. doi: 10.1016/j.jtcvs.2020.01.085

[6] Hennessey, B., Vera-Urquiza, R., Mejia-Renteria, H., Gonzalo, N., \& Escaned, J. (2020). Contemporary use of coronary computed tomography angiography in the planning of percutaneous coronary intervention. The International Journal of Cardiovascular Imaging, 36(12), 2441-2459. doi: 10.1007/ s10554-020-02052-8

[7] Knight, J., Kurtcuoglu, V., Muffly, K., Marshall, W., Stolzmann, P., Desbiolles, L., \& Alkadhi, H. (2009). Ex vivo and in vivo coronary ostial locations in humans. Surgical and Radiologic Anatomy, 31(8), 597-604. doi: 10.1007/s00276-009-0488-9 in Ukraine. The data will be useful for both morphologists and interventional cardiologists and cardiac surgeons for use in clinical practice.

\section{Conclusions}

1. The analysis of the correlation between the values of the height of the location of the orifice of the coronary artery in women in norm and anthropometric indicators did not show a significant relationship.

2. Statistically significant differences between the height of the location of the orifice of the right and left coronary arteries in women were not found.

3. The measured distance from the ring of the aortic valve to the lower and upper edge of the right coronary artery and to the lower and upper edge of the left coronary artery $(p=0.25)$ differed between the studied groups.

[8] Kolossvary, M., Szilveszter, B., Merkely, B., \& Maurovich-Horvat, P. (2017). Plaque imaging with CT-a comprehensive review on coronary CT angiography based risk assessment. Cardiovascular Diagnosis and Therapy, 7(5), 489-506. doi: 10.21037/cdt.2016.11.06

[9] Kulkarni, J. P., \& Paranjpe, V. (2015). Topography, morphology and morphometry of coronary ostia - A cadaveric study. European Journal of Anatomy, 19(2), 165-170.

[10] Merz, A. A., \& Cheng, S. (2016). Sex differences in cardiovascular ageing. Heart, 102, 825-831. doi: 10.1136/heartjnl-2015-308769

[11] Mosteller, R. D. (1987). Simplified Calculation of Body-Surface Area. New England Journal of Medicine, 317(17). doi: 10.1056/ NEJM198710223171717

[12] Nasr, A.Y., \& EI Tahlawi, M. (2018). Anatomical and radiological angiographic study of the coronary ostia in the adult human hearts and their clinical significance. Anatomy \& Cell Biology, 51(3), 164-173. doi: 10.5115/acb.2018.51.3.164

[13] Rosenberg, M. A., Lopez, F. L., Buzkova, P., Adabag, S., Chen, L. Y., Sotoodehnia, N., Mukamal, K. J. (2014). Height and risk of sudden cardiac death: the Atherosclerosis Risk in Communities and Cardiovascular Health Studies. Annals of Epidemiology, 24(3), 174-179. doi: 10.1016/j.annepidem.2013.11.008

[14] Shufelt, C. L., Pacheco, C., Tweet, M. S., \& Miller, V. M. (2018). Sex-specific physiology and cardiovascular disease. In Advances in Experimental Medicine and Biology, 1065, 433454. doi: 10.1007/978-3-319-77932-4 27

[15] Stolzmann, P., Knight, J., Desbiolles, L., Maier, W., Scheffel, H., Plass, A. ... Alkadhi, H. (2009). Remodelling of the aortic root in severe tricuspid aortic stenosis: implications for transcatheter aortic valve implantation. European Radiology, 19(6), 13161323. doi: $10.1007 / \mathrm{s} 00330-009-1302-0$

[16] Team, R. C. (2021). R software (software environment for statistical computing and graphics), version 4.0.5. Retrieved from https://www.r-project.org/

[17] Wang, X., Ren, X.-S., An, Y.-Q., Hou, Z.-H., Yu, Y.-T., Lu, B., \& Wang, F. (2021). A Specific Assessment of the Normal Anatomy of the Aortic Root in Relation to Age and Gender. International Journal of General Medicine, 14, 2827-2837. doi: 10.2147/ IJGM.S312439

ВИСОТА ВІДХОДЖЕННЯ ВІНЦЕВИХ АРТЕРІЙ В ЖІНОК У НОРМІ

Підвальна У. Є., Бешлей Д. М., Мірчук М. З., Матешук-Вацеба Л. Р.

Морфометричний аналіз структур цибулини аорти та вінцевих артерій необхідний для планування кардіохірургічних та ендоваскулярних втручань. Мета дослідження - встановити висоту розташування відходження вінцевих артерій у здорових 
жінок Львова та Львівської області та з'ясувати взаємозалежність показника висоти розташування вічок вінцевих артерій з антропометричними показниками. Для дослідження відібрані 15 зображень комп'ютерної томографії з контрастуванням органів грудної клітки осіб жіночої статі без ураження серця та висхідної аорти (норма). Проведено вимірювання висоти верхнього та нижнього краю вінцевих артерій; висоти пазух Вальсальви. Порівняння середніх величин здійснено за $t$ критерієм Стьюдента. Кореляцію між спостережуваними змінними (вік, зріст, маса тіла, індекс маси тіла, площа поверхні тіла, висота пазух Вальсальви) розраховано за допомогою методу лінійної кореляції Пірсона (r). За результатами дослідження, популяційну групу склали особи другого періоду зрілого віку (46,67 \%) та похилого віку (53,33 \%). За показником індекса маси тіла 80 \% з них страждали надлишковою вагою чи ожирінням I-ІІ ступеня. Середнє значення висоти розташування вічка

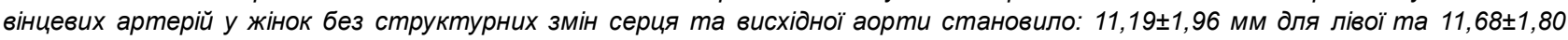
мм для правої. Висота відходження вічок правої та лівої вінцевих артерій були практично однаковими, без статистичної значущості $(p=0,26)$. Аналіз кореляційного зв'язку між значеннями висоти розташування вічок вінцевих артерій не показав вірогідної залежності від зросту, маси, віку, індексу маси тіла та площі поверхні тіла. Встановлено прямий взаємозв'язок між параметрами висоти нижнього краю вічка правої вінцевої артерії та показником висоти верхнього краю правої вінцевої артерії $(r=+0,75, p=0,001)$ і між значенням висоти нижнього краю вічка лівої вінцевої артерії та показником висоти верхнього краю лівої вінцевої артерії ( $r=+0,63, p=0,01)$. Таким чином, аналіз кореляційного зв'язку між значеннями висоти вічок вінцевих артерій у жінок в нормі та антропометричними показниками не показав суттєвої залежності. Статистичної значущості різниці між показниками висоти відходження вічок правої та лівої вінцевих артерій у жінок не виявлено.

Ключові слова: вічка вінцевих артерій, анатомія, комп'ютерна томографія, аорта, вимірювання. 